\title{
PENGARUH STRUKTUR BANGUNAN GEDUNG BERTINGKAT KETIDAKBERATURAN HORIZONTAL TERHADAP BEBAN GEMPA
}

\author{
Muhammad Ramadhan \\ Program Studi Teknik Sipil Universitas Muhammadiyah Sorong \\ Jalan Pendidikan No 27 Kota Sorong, Propinsi Papua Barat \\ Email : ramadhanadam1402@gmail.com
}

\begin{abstract}
ABSTRAK
Indonesia menjadi bagian dari dunia yang memiliki kondisi alam luar biasa indah. Namun hal tersebut harus dibarengi dengan kondisi yang memang cukup beresiko terkait kondisi geografisnya. Berdasarkan berbagai data, Indonesia merupakan salah satu daerah rawan gempa bumi di dunia, karena memiliki kondisi area dengan tektonik yang sangat aktif. Hal ini bisa memberikan dampak bencana alam yang cukup sering dan tidak terprediksi. Wilayah Kota Sorong merupakan wilayah dengan tingkat kegempaan yang tinggi, ini terbukti dari data gempa yang diperoleh dari sumber data. Berdasarkan data sejarah gempa bumi tersebut, sejak tahun 1900 - 2018 wilayah Kota Sorong telah banyak diguncang ribuan gempabumi. Untuk itu perlu ada kajian khusus beban gempa terhadap bangunan yang akan dibangun. Tujuan penelitian yang digunakan adalah mengidentifikasi struktur gedung tidak beraturan yang ditinjau berdasarkan displacement, drift ratio, dan base shear. Metode yang digunakan untuk perhitungan beban gempa adalah statik ekivalen dan respon spektrum.
\end{abstract}

Kata Kunci : ketidakberaturan horizontal; beban gempa; SAP2000, statik ekivalen, respon spektrum 


\section{PENDAHULUAN}

\section{Latar Belakang}

Indonesia menjadi bagian dari dunia yang memiliki kondisi alam luar biasa indah. Namun hal tersebut harus dibarengi dengan kondisi yang memang cukup beresiko terkait kondisi geografisnya. Berdasarkan berbagai data, Indonesia merupakan salah satu daerah rawan gempa bumi di dunia, karena memiliki kondisi area dengan tektonik yang sangat aktif. Hal ini bisa memberikan dampak bencana alam yang cukup sering dan tidak terprediksi.

Ada beberapa sesar (patahan) aktif yang terkenal di Indonesia yaitu Sesar Sumatera, Sesar Cimandiri di Jawa Barat dan sesar Palu-Koro di Sulawesi. Selain itu ada sesar naik Flores, sesar naik Wetar, dan sesar geser Sorong. Semua sesar ini aktif dan memungkinkan terjadinya bencana alam khususnya gempa. Misalnya Kota Sorong merupakan wilayah dengan tingkat kegempaan yang tinggi, ini terbukti dari data gempa yang diperoleh dari sumber data. Berdasarkan data sejarah gempabumi tersebut, sejak tahun 1900 - 2018 wilayah Kota Sorong telah banyak diguncang ribuan gempabumi. Pergerakan ini seringkali terjadi dengan skala Gempa dangkal (kedalaman 0 - 50 km) yang terjadi pada periode 1900 1995 dengan 5,5 skala richter atau lebih membuktikan bahwa beberapa lokasi merupakan daerah aktif gempa di Indonesia.

Dalam perancangan struktur bangunan gedung harus memperhatikan beberapa kriteria perancangan seperti dalam segi biaya harus ekonomis, memiliki nilai estetika yang baik, fungsional dan yang paling penting adalah kekuatan dari struktur bangunan gedung itu sendiri. Dari segi kekuatan suatu struktur harus mampu menanhan beban sendiri bangunan, beban hidup, dan beban gempa. Beban gempa merupakan beban yang paling berpengaruh terhadap bentuk dan struktur bangunan tinggi. Maka dari itu, kita wajib mengantisipasi risiko akibat gempa. Salah satu cara untuk meminimalisasi dampak kerusakan yaitu menghindari bentuks tidak beraturan di bangunan pada tahap perencenaan.

Walaupun denah bangunan yang beraturan dan sederhana telah diketahui mempunyai perilaku yang baik akibat beban gempa, tetapi pada kenyataanya banyak gedung yang bangun secara tidak beraturan karena dilihat dari segi estetika, kondisi lahan yang ada, ataupun karena belum mengerti bangunan. Ketidak beraturan sendiri terbagi menjadi 2 yaitu secara horizontal dan vertikal. Sebagian besar ketidakberaturan gedung adalah secara horizontal. Oleh karena itu, sangat diperlukan analisis kinerja gedung khususnya yang berada di wilayah yang rawan gempa. Dari penjelasan diatas penulis tertatrik mengangkat permasalahan tersebut untuk dilakukan penelitian dengan judul "Studi Analisa Struktur Bangunan Gedung Bertingkat Tidak Beraturan Horizontal Terhadap Beban Gempa" .

\section{Tujuan Penelitian}

Penelitian ini bertujuan untuk mengidentifikasi struktur gedung ketidakberaturan yang ditinjau berdasarkan displacement, drift ratio, dan base shear

\section{STATE OF THE ART}

Adapun penelitian terdahulu yang terkait dengan penelitian ini adalah sebagai berikut :

1. Menurut Purba (2014) menyebutkan bahwa untuk displacement, drift ratio, base shear, berat tulangan dan berat beton terbesar terdapat di struktur gedung tidak beraturan. Serta tidak terdapat perbedaan kinerja struktur berdasarkan performance based design

2. Menurut Nasution dan Teruna (2014) menyebutkan hasil penelitian adalah ada struktur yang memenuhi syarat sebagai struktur dapat dianalisis dengan menggunakan analisis statik ekivalen dan analisis spektrum respons, dikarenakan hasil yang diperoleh dari kedua analisis tersebut menunjukkan besaran yang tidak terlalu jauh perbedaannya dengan nilai analisis statik ekivalen yang sedikit lebih tinggi dikarenakan yaitu berdasarkan RSNI 03-1726-201x struktur dengan ketinggian tidak melebihi 40 meter yang masih bisa dijangkau dengan analisis statik ekivalen, sedangkan pada objek struktur tugas akhir ini ketinggian yang dipakai hanya 28 meter. Maka analisis statik ekivalen masih dapat digunakan pada bangunan 7 tingkat namun lebih akurat dianalisis secara dinamik.

3. Hasil displacement dan base shear pada analisa gaya lateral ekivalen lebih besar dibandingkan pada analisa spektrum respons ragam, maka hasil analisa gaya lateral ekivalen lebih aman jika digunakan untuk penerapan pembebanan gaya gempa dalam perhitungan struktur. Walaupun analisa spektrum respons ragam merupakan analisa gempa yang lebih akurat dan mendekati keadaan yang sebenarnya.Faizah dan Widodo (2013) menyebutkan hasil penelitian adalah Perhitungan pembebanan gempa static ekuivalen pada struktur 5 tingkat dinilai akurat karena memberikan persyaratan yang lebih besar dalam perancangan struktur jika dibandingkan dengan pembebanan gempa dinamik time history. Dan Perhitungan pembebanan gempa static ekuivalen pada 
struktur 10 tingkat atau lebih dinilai tidak akurat karena memberikan persyaratan yang lebih kecil dalam perancangan struktur jika dibandingkan dengan pembebanan gempa dinamik time history. (Francies, Pangouw \& Windah ,2016)

4. Menurut Faizah dan Widodo (2013) Perhitungan pembebanan gempa static ekuivalen pada struktur 5 tingkat dinilai akurat karena memberikan persyaratan yang lebih besar dalam perancangan struktur jika dibandingkan dengan pembebanan gempa dinamik time history. Dan Perhitungan pembebanan gempa static ekuivalen pada struktur 10 tingkat atau lebih dinilai tidak akurat karena memberikan persyaratan yang lebih kecil dalam perancangan struktur jika dibandingkan dengan pembebanan gempa dinamik time history.

\section{METODE}

\section{Tahapan Penelitian}

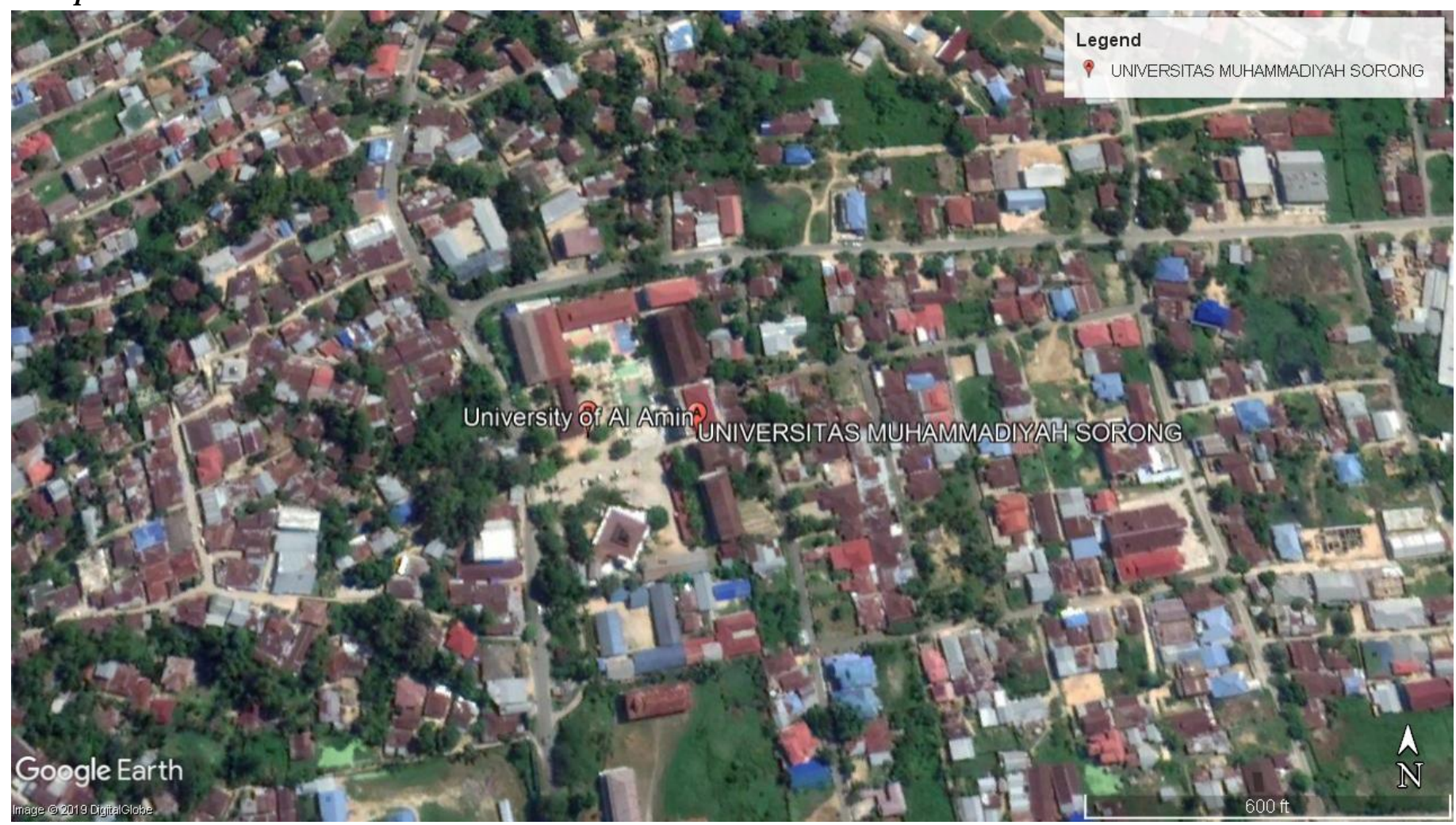

Tahapan penelitian yang digunakan adalah sebagai berikut :

1. Mengumpulkan dan mempelajari berbagai literatur dari berbagai jurnal dan buku.

2. Membuat data perencanaan dari lokasi penelitian, dimensi, bentuk bangunan dan

3. Menganalisis struktur dengan aplikasi SAP2000

4. Mengkomperasi hasil Analisa displacement, drift ratio, base shear

Semua metode penulisan dan analisa dalam artikel ilmiah ini merujuk pada panduan penulisan tugas akhir Fakultas Teknik Universitas Muhammadiyah Sorong tahun 2014 (Pristianto, Amri, \& Rusdi, 2014).

\section{REFERENSI}

1. Pawirodikromo, Widodo. (2012). Seismologi Teknik \& Rekayasa Kegempaan. Pustaka Pelajarl

2. Indarto, H., Tri Cahyo, H.A., Putra, K. C. A. (2013). Aplikasi SNI Gempa 1726:2012

3. Pristianto, H., Amri, I., \& Rusdi, A. (2014, May 9). Pedoman Penulisan Tugas Akhir Fakultas Teknik Universitas Muhammadiyah Sorong 2014. http://doi.org/10.17605/OSF.IO/4VTJM. 